Journal of Agrometeorology 23 (2) : 189-193 (June 2021)

\title{
Assessment on spatial extent of arid and semi-arid climatic zones of India using GIS
}

\author{
NISHA SAHU, G. P. OBI REDDY, B. DASH*, NIRMAL KUMAR and S. K. SINGH \\ ICAR-National Bureau of Soil Survey \& Land Use Planning, Nagpur-440033, India \\ *Corresponding author : benukantha@yahoo.co.in
}

\begin{abstract}
In this study, a quantitative assessment of spatial extent of arid and semi-arid climatic zones of India was performed for the period from 1988 to 2018 using potential evapo-transpiration (PET) calculated by Modified Penman Method, estimated from global climate data sets. Climatic water balances computed for 625 stations across the country are used for classifying to bio-climate types based on moisture index and areas falling under arid climatic zones in India are delineated using ArcGIS 10.5. It was noticed a considerable changes in the country's arid and semi-arid climatic zones between the two periods; 1992 and 2018. Overall, there has been a net percent change in hyper arid, typic arid and semi arid (dry) areas is 5.62, 1.62 and 7.17 percent, respectively. Dryness and wetness are increasing in different parts of the country. There is also change in rainfall, PET and moisture index over a period of time which is vital to determine aridity pattern of any region. Thus, results are of great significance for studying the assessment of temporal and spatial dry climatic water balance of India, which can help immensely in the management of water resources and sustainability of crop production under changing climatic conditions.
\end{abstract}

Key words: Climate change, arid and semi-arid areas, interpolation, GIS

An agro-ecosystem is a complex entity comprising a number of elements which interact with one another to form and stabilize the system. Severe climate and weather events have caused significant disruptions to modern and past societies (Coumou and Rahmstorf 2012; Ross and Lott 2003; Lubchenco and Karl 2012), and there is concern that anthropogenic climate change will increase the occurrence, magnitude, or impact of these events in the future (Meehl et al. 2000; Rahmstorf and Coumou 2011). The agriculture in India mainly depends on monsoon rainfall; about $80 \%$ of total annual rainfall receives as southwest monsoon during June-September. A reduction of the monsoon season over India will have serious consequences for agro-ecological sustainability, even if there is a lengthening of the monsoon season over a wider area.

The Third Assessment Report (TAR) of the Intergovernmental Panel on Climate Change (IPCC) reaffirms that the climate is changing in ways that cannot be accounted by natural variability and Global warming is happening. Global mean temperature have risen $0.6{ }^{\circ} \mathrm{C}$ in the last century, with the last decade being the warmest on record. The arid and semi arid regions of India experienced accelerated warming trends. Mean daily temperatures have increased marginally faster than the national average $\left(0.02{ }^{\circ} \mathrm{C} /\right.$ year $)$ whereas, the average summer monsoon rainfall has decreased by 0.01 -
$1.40 \mathrm{~mm} /$ year, and the monsoon onset and rainfall patterns have become more erratic (www.ASSARadapt.org). The climate change in India is one of the major challenges faced by Indian agriculture, more so in the semi-arid tropics (SAT) of the country. India ranks first among the countries that practice rainfed agriculture in terms of both extent and value of production. The rainfed agro-ecologies cover about 60 per cent of the net sown area and are widely distributed in the country (DOAC, 2011).

Drought is one such extreme phenomenon, and is vital because of its long-term impacts on water resources, agricultural production, and economic activity (Ding et al. 2011). Drought is generally defined as a deficit in soil moisture (agricultural) or streamflow (hydrologic); as such, it can be caused by declines in precipitation, increases in evapo-transpiration, or a combination of the two. Regional changes in precipitation and evapo-transpiration, and the dynamics that drive such changes, are nevertheless more uncertain. Ninety-nine districts in 14 states are declared as drought prone districts by the Central Water Commission (2002). Most of them are concentrated in Andhra Pradesh, Maharashtra, Tamil Nadu, Karnataka, Gujarat and Rajasthan. Low and erratic rainfall coupled with extreme temperatures and intense solar radiation makes these regions the most vulnerable regions in India. 
Table 1: Bio-climatic classification based on moisture index

\begin{tabular}{ll}
\hline Bio-climate class & $\begin{array}{l}\text { Synchronized moisture index } \\
\text { (Mather, 1956) }\end{array}$ \\
\hline Arid & $<-\mathbf{6 6 . 7}$ \\
Hyper arid & $<-88.3$ \\
Typic arid & -66.7 to -83.2 \\
Semi arid & $\mathbf{- 3 3 . 3}$ to $\mathbf{- 6 6 . 6}$ \\
Semi arid (dry) & $\mathbf{- 5 0 . 0}$ to -66.6 \\
Semi arid (moist) & $\mathbf{- 3 3 . 4}$ to -49.9 \\
Sub-humid & $\mathbf{- 0 . 2 0}$ to $\mathbf{3 3 . 3}$ \\
Sub-humid (dry) & 0 to -33.3 \\
Sub-humid (moist) & 0 to +20 \\
Humid & +20 to +100 \\
Perhumid & $>+100$ \\
\hline
\end{tabular}

Table 2: Area under arid and semi-arid climates in India during 1992 and 2018

\begin{tabular}{lccc}
\hline Bio-Climatic Type & $\begin{array}{c}\text { Area in } \\
1992(\%)\end{array}$ & $\begin{array}{l}\text { Area in } \\
2018(\%)\end{array}$ & \% change \\
\hline Hyper Arid & 3.0 & 8.62 & 5.62 \\
Typic Arid & 4.0 & 5.62 & 1.62 \\
Semiarid (Dry) & 8.0 & 15.17 & 7.17 \\
\hline
\end{tabular}

Evapo-transpiration includes both the physical (evaporation) and biological (transpiration) fluxes of moisture from the surface to the atmosphere and can be viewed in terms of actual evapotranspiration (latent heat flux) or evaporative demand (potential evapotranspiration; PET). PET is expected to increase in the future (Scheff and Frierson 2012), due to increase in both total energy availability at the surface (surface net radiation) and the vapor pressure deficit (the difference between saturationand actual vapor pressure; VPD). Chattopadhyay and Hulme (1997) reported that potential evapotranspiration has decreased over the whole country in the monsoon and post-monsoon seasons and the decreasing trend is up to a maximum of about $0.3 \mathrm{~mm}$ day- 1 decade-1 over west-central India. Trends in annual reference crop evapotranspiration (ET0) at Patancheru, Andhra Pradesh indicated a reduction of about $200 \mathrm{~mm}$ from $1850 \mathrm{~mm}$ to $1650 \mathrm{~mm}$ during the 35-year period 1975-2009 (Rao and Wani, 2011).

Terrestrial aridity is widely used to indicate the degree of dryness over a region. Terrestrial aridity is also a measure of water availability for plants or the soil water content over a region and, thus, considered to be a better climate indicator particularly over dry regions from an ecohydrological perspective. Thus, understanding the climatic changes over the arid and semiarid regions in the context ofa warming world is vital for a better management and policymaking which enables to adapt to climate change and promotes long-term resilience.

\section{MATERIALS AND METHODS}

The climatic data (viz. minimum temperature, maximum temperature and precipitation) were downloaded from the website of www.climate.org for the period 1988-2018 for 625 observation sites considering at least one point data in each district across the country. Potential evapo-transspiration (PET) is calculated from a variant of the Modified PenmanMonteith (1991) formula as recommended by FAO (http:// www.fao.org/docrep/x0490e/x0490e06.htm). The PenmanMonteith algorithm is based on physical principles of energy balance overa wet surface, and it is considered to be superior to empiricallybased formulations, which usually consider the effects of temperatureand/or radiation only (Scheff and Frierson 2014). Hargreaves (1994) recommended empirical coefficient $(\mathrm{KT})=0.162$ for 'interior' regions and $\mathrm{KT}=0.19$ for 'coastal' regions.

Based on the mean monthly rainfall and PET values in each location, the climatic water balance was computed using the book-keeping procedure of Thornthwaite and Mather (1955). For computing climatic water balance in different soil types, the available water holding capacity (AWC) of the soils were collected from soil map (1:250,000 scale) of National Bureau of Soil Survey \& Land Use Planning (Singh et al., 2018). Various climatic indices like aridity, humidity and moisture index were computed based on the revised water budgeting approach of Thronthwaite and Mather (1955). The climatic parameters were geo-statistically mapped using ArcGIS 10.5 version by using interpolation techniques. Climates for each year were classified based on the annual moisture index (Table 1) as per classification of Mather (1956). In the present study, the climatic data from 1988-2018 was considered as period II, which is compared with the data used for delineation agro-ecological regions of India (Seghal et al., 1992) as period I.

\section{RESULTS AND DISCUSSION}

Considerable changes in climates in India and at state level between two periods observed in 1992 and 2018 (Table.2 and Table.3). Total percent increase in hyper cold arid in Jammu and Kashmir Union Territory and extends to the districts of Lahul and Spiti and Kinnaur, Himachal Pradesh in 2018 as compared to 1992, whereas, hyper hot arid is increase in the states of Rajasthan and Gujarat. Total percent increase in typic arid in the states Punjab, Haryana, Rajasthan, Gujarat, Karnataka and Andhra Pradesh. In Andhra Pradesh, Kurnool district is shifted from semi arid 


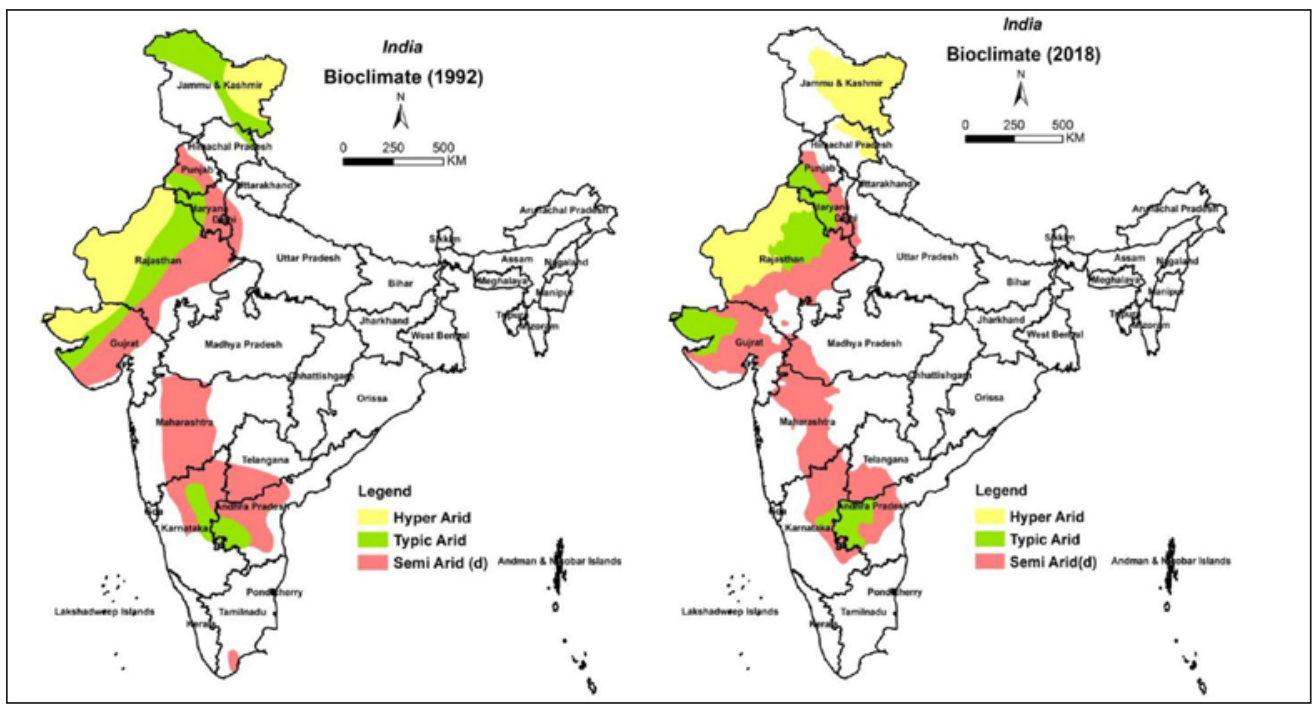

Fig. 1: Spatial distribution of arid and semi-arid climatic zones in India during 1992 and 2018

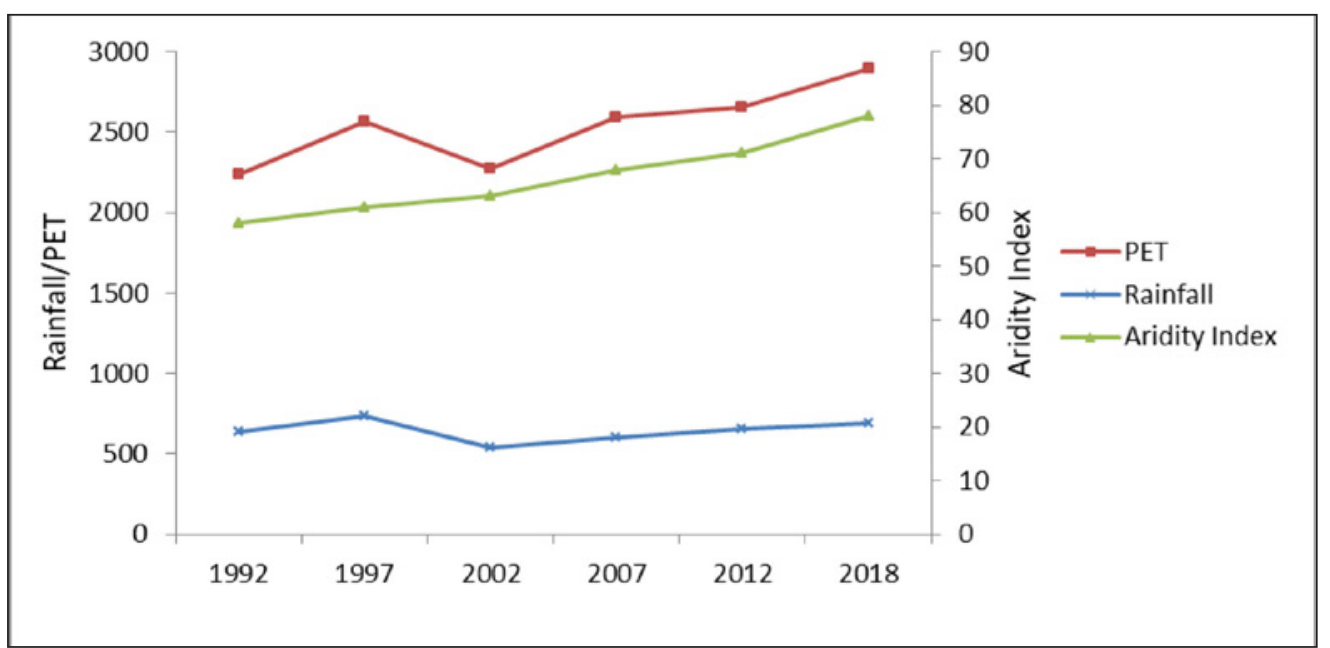

Fig. 2: Average rainfall, PET and aridity index from 1992 to 2018.

(dry) to typic arid in the present study mainly due to increase in dryness. In Karnataka, southern parts of Vijayapura, Bagalkot, Koppal and Chitradurga districts are shifted towards wetter side i.e from typic arid to semi arid (dry), this might be due to the facility of irrigation which led to increase ground water level. However, Devangere, southern parts of Chitradurga, Tumkur, Bengaluru and Chikballapur districts shifted towards drier side i.e from semi arid (moist) to semi arid (dry) this might be due to decrease in number of rainy days and increase in temperature, which in turn increase potential evapo-transpiration.

In the year 1992, there was discontinuous in semiarid (dry) areas when we move from Gujarat to Maharashtra states, but in 2018 scenario the semi arid (dry) areas was increased in Gujarat and Madhya Pradesh states (Fig.1).

In Gujarat, Khera, Anand, northern parts of
Bharuch, Vadodara and Dahod districts and in Madhya Pradesh, Jhabua, Alirajpur, Dhar, Balwani and part of West Nimar and Burhanpur districts dryness increases and shifts towards semi arid (dry) from semi arid (moist). Thus in 2018, the pattern of semi arid (dry) is continuous as we move towards southern parts of the country. In Maharashtra, Pune, Satara and Sangli districts and in Karnataka, Belagavi district shifts towards wetter side due to high rainfall and low potential evapotranspiration i.e from semi arid (dry) to semi arid (moist).

The average annual rainfall is more or less same but the number of rainy days were decreased due to which maximum temperature of a region was increased which is of great concern for agriculture and cause for change in land use. There is also increase in PET which in turn led to increase aridity of particular region. Graph showing the 
Table 3: Change of arid and semi-arid climatic zones at state level during 1992 and 2018 (Area in \% of TGA)

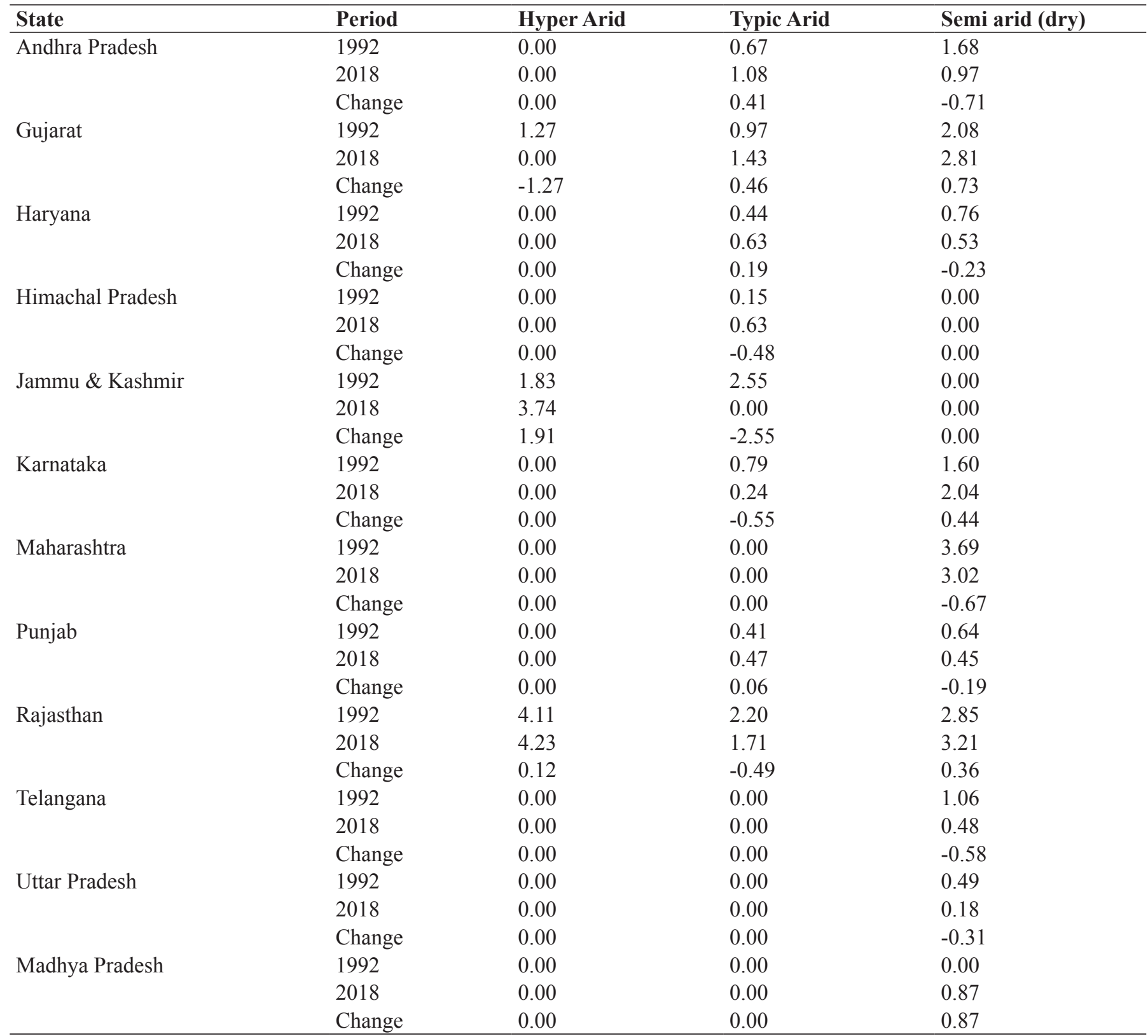

average annual rainfall, PET and aridity index of aridity region (Fig.2).

Country as a whole, net percent change in hyper arid, typic arid and semi arid (dry) areas is 5.62, 1.62 and 7.17, respectively. Increase in the semi arid (dry) areas of Rajasthan, Gujarat, Madhya Pradesh and Maharashtra is due to shifting of semi-arid (moist) areas into semi arid (dry). In this region, groundwater tables and rainfall are low, and the water run-off is high. Annual rainfall is between 100 and $400 \mathrm{~mm}$ or 400 and $800 \mathrm{~mm}$. The northern arid regions, comprising largely of the desert of Rajasthan, the Rann of Kutch and the semi- arid regions of Punjab and Gujarat, are entirely dependent on groundwater and above-the-ground tanks, ponds, other traditional stores of water as no rivers flow through these regions. Thus, temporal and spatial climate variability of the country may be due to natural internal processes within the climate system (internal variability), or due to variations in natural (e.g. solar and volcanic) external forcing (external variability).

Climate change moving towards drier and wetter side in different arid and semi arid dry regions will have an economic impact on agriculture, including changes in farm 
profitability, prices, supply, demand and trade. Agriculture is sensitive to short-term changes in weather and to seasonal, annual and long-term variations in climate. Hence, there is an increased possibility of climate extremes, such as the timing of onset of monsoon and intensities and frequencies of droughts and floods, which will pose serious risks to crop production systems and food security in general.

\section{CONCLUSION}

Analysis of the climate data indicates the increase in hyper cold arid areas in Jammu \& Kashmir and Himachal Pradesh, hyper hot arid in the states of Rajasthan and Gujarat in 2018 as compared to 1992 . Overall, there has been a net percent change in hyper arid, typic arid and semi arid (dry) areas is 5.62, 1.62 and 7.17, respectively. Dryness and wetness are increasing in different parts of the country. Thus, results are of great significance for studying the assessment of temporal and spatial dry climatic water balance of India, which can help immensely in the management of water resources and sustainability of crop production under changing climatic conditions. There is an urgent need to enhance the awareness about the climate change using innovative science-based information and communication tools along with enabling policies and institutional options.

\section{REFERENCES}

Chattopadhyay, N. and Hulme, M. (1997). Evaporation and potential evapotranspiration in India under conditions of recent and future climate change. Agric. Forest Meteorol., 87:55-73.

Coumou, D. and Rahmstorf, S. (2012). A decade of weather extremes. Nature Climate Change. 2(7):1-6.

Ding, D., Maibach, E.W., Zhao, X., Roser-Renouf, C. and Leiserowitz, A. (2011). Support for climate policy and societal action are linked to perceptions about scientific agreement. Nature Climate Change. 1:462-466.

DOAC. (2011). Annual Report 2010-11. Department of Agriculture and Cooperation, Ministry of Agriculture, Government of India.http://agricoop. nic.in/Annual report2010-11/AR.pdf.

Hargreaves, G. H. (1994). Simplified coefficients for estimating monthly solar radiation in North America and Europe.Department of Biology and Irrigation Engineering, Utah State University, Logan, Utah.

Lubchenco, J. and Karl, T.R. (2012). Predicting and managing extreme weather events. Phys. Today. 65(3): 31-37.

Meehl, G.A., Karl, T., Easterling, D.R., Changnon, S., Pierke, R., Changnon, D., Evans, J., Groisman, P.., Knutson,T .R., Kunkel, K.E., Mearns, L.O., Parmeson, C., Pulwarty, R., Root, T., Sylves, R.T., Whetton, P. and Zwiers, F. (2000). An introduction to trends in extreme weather and climate events: observations, socio-economic impacts, terrestrial ecological impacts and model projections. B. Am. Meteorol. Soc., 81(3):413-416.

Singh, S.K., S. Chatterji, S. Chattaraj, and P.S. Butte (2018). ICAR-NBSS\&LUP Technologies. NBSS Publ. No.176, ICAR-NBSS\&LUP, Nagpur p.90.

Sehgal, J.L., Mandal, D.K., Mandal, C., Vadivelu, S. (1992). Agro-Ecological Regions of India.Technical Bulletin, NBSS Publ. 24, Nagpur, India.P. 130.

Rahmstorf, S. and Coumou, D. (2011). Increase of extreme events in a warming world. PNAS, 10B(44): $17905-$ 17909.

Rao A.V.R.K., and Suhas P. Wani (2011). Evapotranspiration paradox at a semi-arid location in India. $J$. Agrometeorol., 13 (1): 3-8.

Ross, T. and Lott, N. (2003).A climatology of 1980-2003 extreme weather and climate events. National Climatic Data Center Technical Report no. 2003-01.

Scheff, J. and Frierson, D.M.W. (2012). Twenty-First century multimodel subtropical precipitation declines are mostly mid latitude shifts. J. Clim., 25(12): 43304347.

Scheff, J. and Frierson, D.M.W. (2014).Scaling potential evapotranspiration with greenhouse warming. $J$. Clim., 27(4). DOI:10.1175/JCLI-D-13-00233.1.

Thornthwaite C.W. and Mather J.R. (1955).The water balance.Publications in climatology. Vol. VIII. No.1. Drexel Institute of Technology, Laboratory of climatology, New Jersey. 